\title{
Szemle
}

\section{ERŐFESZÍTÉS ALAPÚ KONTROLL ÉS VÉGREHAJTÓ FUNKCIÓK AZ ÖNSZABÁLYOZÁSBAN*}

\author{
D. MOLNÁR ÉVA \\ SZTE Neveléstudományi Intézet \\ E-mail: medu@edpsy.u-szeged.hu
}

Beérkezett: 2016. augusztus 13. - Elfogadva: 2017. augusztus 13.

\begin{abstract}
Az önszabályozás egyre intenzívebb kutatása során bizonyítottá vált, hogy az iskolaérettségben és a sikeres iskolai boldogulásban az önszabályozás képessége alapvetố szerepet tölt be. A viselkedéses/temperament alapú és kognitív/neurálishálózat-szintû kutatások többnyire egymástól függetlenül foglalkoztak az önszabályozás vizsgálatával, és míg az elóbbi az erôfeszités alapú kontrollt, az utóbbi a végrehajtó funkciókat tekinti az önszabályozás alapjának. A két különböző területen végzett kutatások eredményei ugyanakkor azt mutatják, hogy bár másfajta elméleti és módszertani keretet használnak, felfedezhetók közös aspektusok és komponensek. Hazai vonatkozásban kevésbé ismert az erôfeszités alapú kontroll kutatása és a végrehajtó funkciókkal történő összehasonlítása. Jelen tanulmány a két területen végzett vizsgálatok fontosabb eredményeit, az erófeszités alapú kontroll és végrehajtó funkciók értelmezésének, hasonlóságának és különbségének bemutatását, valamint az önszabályozásban történô integrálásuk elméleti hátterét vázolja fel.
\end{abstract}

Kulcsszavak: erôfeszités alapú kontroll, végrehajtó funkciók, önszabályozás

* A szerzô a tanulmány megírása alatt Bolyai János Kutatási Ösztöndíjban részesült. 
Az utóbbi évtizedekben az önszabályozás egyre intenzívebb kutatása és alaposabb értelmezése kapcsán egyértelmúvé vált, hogy az iskolaérettségben és a sikeres iskolai boldogulásban az önszabályozás képessége alapvetô szerepet tölt be (Liew, 2012). A viselkedéses/temperament alapú és kognitív/neurálishálózat-szintú kutatások többnyire egymástól függetlenül foglalkoztak az önszabályozás vizsgálatával, és míg az elôbbi az erôfeszítés alapú kontrollt (Rothbart és Bates, 2006), az utóbbi a végrehajtó funkciókat (pl. Patrick, Blair és Maggs, 2008) tekinti az önszabályozás alapjának. A két különbözó területen végzett kutatások eredményei ugyanakkor azt mutatják, hogy bár másfajta elméleti és módszertani keretet használnak, felfedezhetôk közös aspektusok és komponensek. Éppen ezért az utóbbi években megfigyelhetô a két terület összehasonlítására és integrálására tett törekvés (lásd Blair és Razza, 2007; Liew, 2012; Simonds, Kieras, Rueda és Rothbart, 2007; Zhou, Chan és Main, 2012).

Hazai vonatkozásban kevésbé ismert az erôfeszítés alapú kontroll kutatása és a végrehajtó funkciókkal történô összehasonlítása. Jelen tanulmány célja az erôfeszítés alapú kontroll és végrehajtó funkciók értelmezésének, hasonlóságának és különbségének bemutatása magyar nyelven, valamint integrálásuk elméleti hátterének és a gyakorlat szempontjából lehetséges következményeinek felvázolása.

\section{ERŐFESZÍTÉS ALAPÚ KONTROLL}

Az erőfeszítés alapú kontroll ${ }^{1}$ (EC - effortful control) fogalmát Mary K. Rothbart és munkatársai (Rothbart és Ahadi, 1994; Rothbart és Bates, 2006) vezették be, akik a temperamentumkutatás kiemelt képviselôi. A temperamentumot a személyiség „affektív, viselkedéses és figyelmi magjának" (100) tekintik, ami az egyéni különbözôségekben (a reaktivitásban - a különbözô ingerekre való automatikus reagálásban, és az önszabályozásban - a reaktivitás mértékének szándékos szabályozásában) nyilvánul meg, és ennek részeként értelmezik az erôfeszítés alapú kontrollt is. Ahadi, Rothbart és Ye (1993) kérdôíves vizsgálattal a temperamentum három fő faktorát különítették el, amelyek közül kettôrôl azt feltételezték, hogy a születés után, az elsố hónapokban megjelenik és reaktív. Az egyik az extraverzió (surgency), amelybe az aktivációs szint, a szociabilitás, az impulzivitás és a magas intenzitású élménykeresés tartozik, a másik pedig a negatív érzelmi viszonyulás (negative affectivity), amely a félelem, harag, szomorúság, diszkomfort érzés megnyilvánulására vonatkozik. A temperamentum harmadik faktoraként az erôfeszitésalapú kontrollt nevezték meg, ami késôbb manifesztálódik, mint az eloobb említett két faktor, és magában foglalja a gátlást, a figyelem fókuszálását/váltását, valamint az alacsony intenzitású élmények kedvelését.

Rothbart és Bates (2006) meghatározása alapján az erôfeszítés alapú kontroll „olyan képesség, amely a domináns választ gátolja és/vagy a nem-domináns választ aktiválja” (129). A szerzók képességként definiálják, és bár az életkor elôrehaladtával, a bonyolultabb helyzetek kapcsán múködése kiegészül egyéb folyamatokkal, a figyelemváltás, a tevékenységkontroll, a szándékos figyelem és a gátlás dimenziói stabilnak mutatkoznak (Evans és Rothbart, 2007; Putnam, Gartstein és Rothbart, 2006). Mások

${ }^{1}$ Magyar fordításban találkozhatunk még az erôfeszítéses kontroll kifejezéssel is (pl. Buda, 2014). 
is többféle komponenst különböztetnek meg az erőfeszítés alapú kontroll múködése során, ugyanakkor egységes képességnek tekintik, amit mérésmetodikai eljárásokkal is alátámasztanak (Rothbart, Ahadi, Hershey és Fisher, 2001; Bridgett, Oddi, Laake, Murdock és Bachmann, 2013).

Az erôfeszítés alapú kontroll a csecsemókor végén (másfél éves kor körül) manifesztálódik (a szülôii, gondozói vélekedések alapján korábban nem vehetô észre; Ahadi, Rothbart és Ye, 1993), amikor a kisgyerekek képesek figyelmüket szándékosabban irányítani, és érzelmeiket, viselkedésüket proaktív módon befolyásolni. Míg a két, két és fél éves kor elôtti gyerekeknek a tevékenységváltás és gátlás (pl. a játék folytatása helyett teljesíteni a szülői kérést, és a játékot egy másik tevékenységre váltani) nagyobb nehézséget okoz, ettôl a kortól kezdôdôen egyre nagyobb fejlôdést mutatnak mind viselkedésük kontrollálásában, mind pedig tevékenységük gátlásában és a kívánt viselkedés aktiválásában (Rothbart, Sheese és Posner, 2007). Ugyanakkor nagy egyéni különbségek mutatkoznak a gyerekek között, és akárcsak a temperamentum többi aspektusánál, az erôfeszítés alapú kontroll esetében is ennek egyrészt biológiai (veleszületett, méhen belüli hatások), másrészt környezeti (szülői gondoskodás) meghatározó okai vannak (Eisenberg és mtsai, 2014). A genetikai meghatározottságot ikerkutatások alapján mondták ki (Goldsmith, Pollak és Davidson, 2008), míg a környezeti hatásokat fôként a szülői nevelési stílus vizsgálatokból állapították meg (Eisenberg és mtsai, 2014). Ez utóbbi szerint az erôfeszítés alapú kontroll (és az önszabályozás) pozitív összefüggést mutat a meleg, támogató anyai viselkedéssel, és negatív kapcsolatban áll a túlzottan kontrolláló szülői nevelési stílussal.

Bizonyított, hogy a gyerekkori temperamentumbeli jellegzetességek jól meghatározott elốrejelzôi a késôbbi viselkedésnek (Rothbart és Bates, 2006). A vizsgálatok azt mutatják, hogy az erófeszítés alapú kontrollnak nagy szerepe van az iskolai boldogulásban, a szociális kapcsolatok sikeres kezelésében és a tanulmányi eredményességben egyaránt (Eisenberg, és mtsai, 2014). Ahhoz, hogy egy olyan szorosan strukturált környezetben, mint amilyen az iskola, a gyerekek hatékonyan megfeleljenek (mind szociális, mind tanulmányi szempontból), szükség van a figyelem irányítására és a viselkedés kontrollálására (a tanár utasítására figyelni, az egymás után következó feladatokat észben tartani, a menet közben fellépô emóciókat szabályozni, osztálytársakkal való kapcsolatokat kezelni stb.) (Liew, 2012). A kognitív képességekkel való összehasonlítás során összefüggést mutattak ki a matematikai és olvasási képesség és az erőfeszítés alapú kontroll között (Blair és Razza, 2007; McClelland, Cameron, Connor, Farris, Jewkes és Morrison, 2007), ez azt jelenti, hogy jobb matematikai és olvasási képességgel rendelkeznek azok, akiknek magas az erôfeszítés alapú kontrolljuk. Továbbá longitudinális vizsgálatokból az derül ki, hogy az erôfeszítés alapú kontroll jó előrejelzôje a késôbbi olvasási teljesítménynek (Liew, McTigue, Barrois és Hughes, 2008), valamint jobban elôrejelzi a tanulmányi átlagot, mint az elôzô félévi átlag vagy a tanár-diák kapcsolat minôsége (Valiente, Le mery-Chalfant, Swanson és Reiser, 2008). Ezen kívül pozitív összefüggést mutattak ki a magas erôfeszítés alapú kontroll és a szociális kompetencia között is (Eisenberg és mtsai, 2014). A gyenge erôfeszítés alapú kontroll ugyanakkor előrevetítheti a késôbbi agresszív, antiszociális viselkedést, valamint depresszív tünetek megjelenését (Dennis és Brotman, 2003). 


\section{VÉGREHAJTÓ FUNKCIÓK}

A végrehajtó funkciók (EF - executive functions) vizsgálatával több tudományterület is foglalkozik, éppen ezért többféle megközelítésben, sokféle meghatározása látott napvilágot. Zhou és munkatársai (2012) három nagyobb csoportba sorolják ezeket a különbözô megközelítéseket, attól függôen, hogy milyen szempont alapján értelmezik a végrehajtó funkciókat. Ezek szerint vannak a végrehajtó funkciókat $a$ ) egységes konstruktumként, $b$ ) többdimenziós komponensként, illetve $c$ ) egységes konstruktumként továbbbontható komponensekkel értelmezô kutatások. Az elsô megközelítésben a végrehajtó funkciókat olyan egységes, központi végrehajtó rendszerként értelmezik, amely más kognitív rendszereket és alfolyamatokat szabályoz (Baddeley,1986; Shallice, 1988). A második értelmezésben a végrehajtó funkciók több dimenzió összehangolt múködéseként írhatók le. Ezek közül legismertebb Miyake, Friedman, Emerson, Witzki és Howerter (2000) munkája, akik konfirmatív faktoranalízissel a munkamemória, a váltás (feladatok, utasítások között) és a gátlás dimenzióit határozták meg a végrehajtó funkciókon belül. A harmadik megközelítésben egy-egy képességet emelnek ki, ami koordinálja a többi végrehajtó képesség múködését. Garon, Bryson és Smith (2008) a szándékos és szelektív figyelmet, Jacques és Marcovitch (2010) a munkamemóriát tekintik a végrehajtó funkciókon belül függetlenül múködő képességek mediátorának, ami összehangolja a többi folyamat múködését.

Összességében megállapítható, hogy a végrehajtó funkciók alatt olyan magasszintû kognitív folyamatok komplex, összehangolt múködését értik, amelyek révén megvalósul a cselekvéskontroll, a problémamegoldás és célvezérelt tevékenységek tervezése, megszervezése és végrehajtása (Csépe, 2005; Miyake és mtsai, 2000; Tánczos, 2012). Elsôsorban nem képességként értelmezik, hanem olyan folyamatokként, amelyek az észlelés, a gondolkodás, a cselekvés végrehajtásáért felelôs képességek múködtetésében játszanak fontos szerepet (McCloskey, Perkins és Van Divner, 2009).

A különbözô elméleti megközelítések mellett egységesnek látszik három központi folyamat megnevezése: a gátlás, a munkamemória és a kognitív rugalmasság (vagy más néven váltás) (Diamond, 2013), amelyek a végrehajtó funkciók értelmezése során mind megjelennek. A gátlás meghatározása itt is a vágyaknak és az impulzív reakcióknak való ellenállásra, az eltervezett tevékenység melletti kitartásra vonatkozik. A munkamemória (információk elmében tartása és azokkal való múveletvégzés) értelmezésében elkülönül a rövid távú memóriától való megkülönböztetése, ez utóbbi csupán az információk elmében való tartására vonatkozik. A kognitív rugalmasság az elôzó kettôn alapul, ami a megváltozott környezeti tényezókhöz való gyors és rugalmas alkalmazkodást, a dolgok különbözô perspektívából való szemlélését jelenti (Diamond, 2013). E három központi végrehajtó funkció múködése összefügg, de egymástól függetlenül is megtörténhet, illetve fejlettségük eltérô lehet (McCloskey, Perkins és Van Divner, 2009).

Friedman és Miyake (2017) az egyik legkurrensebb, egységesség/diverzitás (unity/ diversity) modell megalkotásával arra keresték egyrészt a választ, hogy a végrehajtó funkciók múködését milyen tényezôk, faktorok befolyásolják, másrészt az agyi háttér alapján mely komponensei egységesek és melyek különbözók. Megállapításuk szerint a végrehajtó funkciók egységességet és különbözôséget egyaránt mutatnak. Egysé- 
gesnek tekinthetô az, hogy mindenkinél ugyanazok a végrehajtó folyamatok (gátlás, munkamemória, váltás) múködnek, és ezek az agy különbözô, de jól beazonosított területeihez kapcsolhatók. Ugyanakkor számos egyéni változata lehetséges annak, ahogyan ezek a folyamatok egymással összekapcsolódnak, amilyen szinten múködnek vagy amilyen teljesítményt eredményeznek, és ez adja a végrehajtó funkciók diverzitását. Ugyanakkor ikerkutatások alapján kimutatták, hogy a végrehajtó funkciók múködése nagymértékben az öröklés által, genetikailag meghatározott. Ennek ellenére, úgy gondolják, hogy a környezeti hatások eredményesen befolyásolhatják a végrehajtó funkciók változását, éppen a sokféle összekapcsolódási lehetôség, a diverzitás miatt (Friedman és Miyake, 2017).

A szakirodalomban egyelốre vitatott az a kérdés, hogy a végrehajtó funkciók megjelennek-e 5 éves kor elôtt; empirikus adatok alapján az látszik, hogy iskoláskor elôtt inkább egyfaktorú, egydimenziós konstruktumként lehet értelmezni, amelyben még nem különülnek el egyértelmúen az egyes folyamatok (Wiebe és mtsai, 2011). Ezt a megállapítást a végrehajtó funkciók latens struktúrájának konfirmatív faktoranalízissel történô ellenôrzése kapcsán tette több kutató is (pl. Hughes, Ensor, Wilson és Graham, 2010; Wiebe és mtsai, 2011). Az eredmények azt mutatták, hogy a 3-4 éves korú gyerekek részvételével zajlott vizsgálatban (ahol különböző végrehajtó funkciókat igénylô feladatokat vizsgáltak), az egydimenziós modell FIT-értékei voltak a leginkább megbízhatóak, a kétdimenziós (munkamemória, gátlás) vagy háromdimenziós (az elóbbiek kiegészülve a váltással) modell értékei nem voltak jók, így a többdimenziós struktúrát elvetették. Mivel a végrehajtó funkciók múködése szorosan összekapcsolódik az agy prefrontális kéreg fejlôdésével, megjelenését éppen ezért ennek az agyi területnek az intenzíven fejlôdő fázisához kapcsolják, ami 3-5 éves kor között indul meg (és kora gyermekkortól felnôttkorig tart, Diamond, 2013), és a folyamatok differenciálódása is ettôl a kortól lesz megfigyelhetô és ellenôrizhetô (Wiebe és mtsai, 2011).

Szerepét a személyiség egészére kiterjedôként határozzák meg. Összefüggésbe hozzák a mentális és fizikai egészséggel, az életminôséggel, az iskolaérettséggel, az iskolai és a mindennapi életben való sikerességgel, a kognitív, szociális és pszichológiai fejlôdéssel (Diamond, 2013). Longitudinális vizsgálatokból az is kiderül, hogy azok a gyerekek, akik 3 és 11 éves koruk között magasabb kontrollfunkciókkal (gátló funkciókkal) rendelkeztek (tudtak várni a sorukra, nem kalandoztak el olyan könnyen, nem voltak túlzottan impulzívak stb.), serdülőkorukban sikeresebb iskolai eredményekkel és szociális kapcsolatokkal rendelkeztek, felnőttkorukra pedig kiegyensúlyozottabb, megelégedettebb életet éltek (Moffitt és mtsai, 2011).

A végrehajtó funkciók és iskolai eredményesség összefüggését hazai vonatkozásban Tánczos és munkatársai (2014) vizsgálatából ismerhetjük, akik a tanulmányi átlag és egyéb tantárgyak (matematika, magyar nyelv és irodalom, természettudomány) kapcsán mutatták ki a végrehajtó funkciók egyes területeinek bejósló szerepét. A nemzetközi mezônybôl leginkább a jó eredményekkel záruló fejlesztô programokat érdemes kiemelni. Egyre több kutatás hívja fel a figyelmet a kognitív funkciókat (munkamemória, gátlás, figyelem-váltás) fejlesztô programok hatására, amelyek bizonyítottan az önszabályozó képesség fejlôdését eredményezik emocionális, viselkedéses és figyelmi területek múködtetésén keresztül (Barnett és mtsai, 2008; Bierman és mtsai, 2008; Diamond és mtsai, 2007). Ezen a területen legismertebb programok: a Tools of the 
Mind (Bodrova és Leong, 2007), a Head Start REDI (Bierman és mtsai., 2008), a CogMed számítógépes tréning (Klingberg, 2010), valamint a PATHS (Promoting Alternative Thinking Strategies) program (Kam, Greenberg és Kusche, 2004). Ezek mellett más, a végrehajtó funkciókat nem közvetlen módon fejlesztô programok/tevékenységek (pl. keleti harcmúvészetek, jóga, meditáció) jótékony hatását is kimutatták a végrehajtó funkciók fejlôdésére nézve (Diamond, 2013), azonban ezek a közvetett hatás miatt többnyire nem rendelkeznek jól kidolgozott elméleti és kutatási kerettel.

\section{HASONLÓSÁGOK ÉS KÜLÖNBSÉGEK AZ ERÖFESZÍTÉS ALAPÚ KONTROLL ÉS A VÉGREHAJTÓ FUNKGIÓK ÉRTELMEZÉSÉBEN}

A két konstruktum összehasonlítását, az értelmezések összevetését többen is megkísérelték az utóbbi idôkben (Zhou és mtsai, 2012; Blair és Razza, 2007; Liew, 2012; Simonds és mtsai, 2007). Ezekból az összehasonlításokból kiderül, hogy van néhány folyamat, amit mindkét elméleti megközelítés használ (pl. gátlás, figyelem), és emellett vannak olyan folyamatok is, amelyek megnevezése és szerepe eltér a két hagyományos elméleti keretben.

Az összehasonlítások eredményeként az egyik legjobban azonosítható közös aspektus a gátlás, ami kifejezésében (inhibition, inhibitory control) egyértelmúen, meghatározásában pedig részben mutat egyezést a két különbözô területen. Míg az erôfeszítés alapú kontroll szakirodalmában a gátlás alatt a Stroop (1935) által megalkotott definíciót értik és használják (a domináns, automatikus vagy előfeszített válaszok szándékos legátlása), a végrehajtó funkciók kapcsán komplexebb értelmezését adják ennek a folyamatnak. Diamond (2013) a gátlás funkciót kiegészíti az interferenciakontroll folyamataival, ami alatt a szelektív figyelem és kognitív gátlás is megvalósul.

Az összehasonlításokban másik közös komponensként a figyelmet nevezik meg (attention, executive attention), ami a temperamentumkutatások során az erôfeszítés alapú kontroll meghatározó alapja (Rothbart, Sheese és Posner, 2007), míg a végrehajtó funkciók vizsgálatában szintén központi szerepet szánnak ennek a képességnek: feladata a többi komponens összehangolása (Garon, Bryson és Smith, 2008). Ugyanakkor Blair és Ursache (2011) kiemelik, hogy bár a figyelem közös elemnek tekinthetô, de másként múködik a két területen. Mivel az erôfeszítés alapú kontroll (és a temperamentum) alapját egy olyan neurobiológiai rendszer képezi, amely a kogníció és emóció interakciójáért felel (és ez fôként a limbikus rendszerben helyezkedik el), ezért a figyelem a tapasztalatok gyors felismerését és automatikus, nem tudatos folyamatokat foglal magában. Ezzel szemben a végrehajtó funkciók kapcsán lassú, nagyobb erôfeszítést igénylô, akaratlagos folyamatokért felel. Mindemellett Diamond (2013) meghatározásában a figyelem (executive attention) szinonimája a szelektív vagy fókuszált figyelemnek, amit a gátló funkció egyik szintjének tekint a végrehajtó funkciók értelmezése során.

A folyamatok leírása és értelmezése mellett a vizsgálati módszerekben is találhatunk hasonlóságokat. Egyrészt mindkét kutatási területen használnak kérdôíves vizsgálatot, ami arra enged következtetni, hogy ezzel a módszerrel is mérhetô az adott konstruktum: erôfeszítés alapú kontroll - pl. CBQ - Child Behavior Questionnaire (Rothbart, Ahadi, Hersey, és Fisher, 2001); ECS - Effortful Control Scale (Lonigan és 
Phillips, 2001), végrehajtó funkciók - pl. BRIEF - Behavior Rating Inventory of Executive Function (Gioia, Isquith, Retzlaff és Espy, 2002). Másrészt egyéni feladathelyzetben, a viselkedésre irányuló vizsgálatokban is felfedezhetô egyezés. Például a Go/No Go feladatokat (motoros válasz adása vagy nem adása egy bizonyos jelzôingerre, mint pl. a Simon-teszt esetében, lásd Redick, Gay, Calvo és Engle, 2011) mind az erôfeszítés alapú kontroll (pl. Lengua, Honorado, és Bush, 2007), mind pedig a végrehajtó funkciók (pl. Carlson, 2005) mérésére alkalmazták. A különbözố típusú Stroop-feladatok alkalmazása kapcsán ugyanez elmondható. A HTKS (Head-Toes-Knees-Shoulders; Ponitz, McClelland, Jewkes, Connor, Farris és Morrison, 2008) az erôfeszítés alapú kontroll egyik leggyakrabban alkalmazott vizsgálati eszköze, ami egyfajta viselkedéses Stroopnak tekinthetô (a vizsgálat során négy különböző utasítás ellenkezójét kell mutatni). A végrehajtó funkciók kapcsán a hagyományos szín-Stroop vagy a Day-Night Stroop (a kép jelentésével ellenkezó kifejezést kell mondani) alkalmazása figyelhetô meg (lásd Gerstadt, Hong és Diamond, 1994; Carlson, 2005). Ezek a módszertani átfedések egyrészt arra engednek következtetni, hogy a vizsgálatokban is összemosódik a két fogalom értelmezése, másrészt ezen mérôeszközök révén épp azokat a folyamatokat vizsgálják (pl. gátlás, figyelem), amelyek azonosak és átfedést mutatnak a két területen. Ebben az esetben az azonos mérôeszköz különbözó elméleti keretekben való alkalmazása elfogadhatóvá válik.

A neurális háttér azonosítása kapcsán az erôfeszítés alapú kontroll esetében kevesebb vizsgálati eredmény született, mint a végrehajtó funkcióknál. Ugyanakkor, mindkét konstruktum múködésében szerepet játszó agyi területként a prefrontális kéreg különbözô részeit nevezték meg. Az erófeszítés alapú kontroll esetében a figyelem múködésénél az elülsô cinguláris kéreg és a laterális prefrontális kéreg aktiválását azonosították (Fan, McCandliss, Fossella, Flombaum és Posner, 2005). Más, esettanulmányon alapuló kutatások a ventromediális prefrontális kéreg múködését összekapcsolták a temperamentum egyes dimenzióival, az egészséges emocionális és szociális fejlôdéssel. Kimutatták, hogy e terület kora gyermekkori sérülése együtt jár az emóciók alacsony szabályozásával (a harag, frusztráció gyenge kezelésével), gyenge döntéshozatallal és alacsony lelkiismeretességgel (Anderson, Damasio, Tranel, és Damasio, 2000). Ezek a problémák ugyanakkor hosszú távúnak bizonyultak; azok a gyerekek, akik kiskorukban sérülést szenvedtek az agy ventromediális területén, felnôttkorukban sem tudtak felelôsségteljes munkát végezni, gyenge szociális kapcsolatokkal rendelkeztek (Garon és Moore, 2006). Serdülôkkel végzett longitudinális kutatás során a prefrontális kéreg három (elsülsố cinguláris kéreg, a dorsolaterális és ventrolaterális prefrontális kéreg) területét és változását ellenôrizték MRI-vizsgálattal, az erôfeszítés alapú kontrollal összefüggésben (Vijayakumar, Whittle, Dennison, Yücel, Simmons és Allen, 2014). Az eredmények nemek közötti különbségeket mutattak ki: az agyi területek változásával nem járt együtt az erőfeszítés alapú kontroll fejlődése a fiúk esetében, viszont a lányok esetében csökkenés mutatkozott. Ez ellentmond azoknak a vizsgálatoknak, amelyek az önszabályozás fejlődését összefüggésbe hozzák a serdülookori agyi fejlôdéssel (Rothbart és mtsai., 2007), ám a szerzôk elsôsorban mérésmetodikai problémára (kérdôíves vizsgálat) vezetik vissza ezt az eredményt, és olyan feladatok bevonását tartják fontosnak, amelyben a háttérben zajló folyamatok (pl. gátlás, váltás) konkrét ellenôrzése megvalósulhat. 
A végrehajtó funkciók kapcsán egyértemúbb eredmények születtek. Kimutatták, hogy az orbitofrontális kéreg az egyszerúbb szabályok, a ventrolaterális és dorsolaterális prefrontális kéreg pedig a feltételes szabályok, valamint a szabályok összekapcsolásának múködéséért felelnek (Bunge és Zelazo, 2006, idézi Zhou és mtsai, 2012). A végrehajtó funkciók esetében tehát hangsúlyosabban jelennek meg az agyi háttér feltárására tett kísérletek, amelyekbôl kiderül, hogy a funkciók múködésében egyszerre több agyi terület is aktiválódik (McCloskey, Perkins és Van Divner, 2009), de a pontos összefüggések feltárására alaposabb, mélyreható elemzésekre lenne szükség, amit Diamond (2013) napjaink egyik legnagyobb kihívásának tekint.

A hasonlóságok ellenére az erófeszítés alapú kontrollt és a végrehajtó funkciókat mégsem tekintik egy és ugyanazon konstruktumnak (Zhou és mtsai, 2012). Ennek egyik okaként azokat a komponenseket említik, amelyek nem találhatók meg mindkét értelmezésben. Ilyen a munkamemória, amely a végrehajtó funkciók vizsgálatában központi helyet foglal el, míg az erôfeszítés alapú kontroll esetében nem jelenik meg ennek vizsgálata (Liew, 2012; Bridgett és mtsai, 2013), annak ellenére sem, hogy a munkamemóriában aktiválódó folyamatok némelyike (pl. tervezés, hibák észlelése, tudatosítása és korrigálása) megjelenik az erôfeszítés alapú kontroll során is (Rothbart és Bates, 2006), de az elnevezésben nincs egyezés.

A másik jelentôsebb különbség, amit az összehasonlítások is kiemelnek (Zhou és mtsai, 2012), a kognitív területek és emóciók lefedésének eltérésében jelentkezik. Míg az erôfeszítés alapú kontroll vizsgálatokban hangsúlyosabban jelennek meg az emóciókkal kapcsolatos kérdések, a végrehajtó funkciók vizsgálataiban fóként a kognitív területek kerülnek elôtérbe. Ezt a hideg (cool) és forró (hot) rendszerek (Mischel, Ayduk, and Mendoza-Denton, 2003; Zelazo és Cunningham, 2007) csoportosításával és ellenôrzésével lehet alátámasztani (elôbbi a kognitív, utóbbi az emocionális területekre vonatkozik). Az erófeszítés alapú kontroll szerepét az emocionális területek (pl. öröm, agresszió kezelése, lásd MacDonald, 2008) mellett a szociális helyzetek hatékony kezelése (Eisenberg és mtsai, 2014), az ego-reziliencia (kitartás, hatékony alkalmazkodás a környezethez, Liew és mtsai, 2008) és a jutalmazás késleltetése (Spinrad és mtsai, 2007) kapcsán is kiemelik. Ezek a területek a végrehajtó funkciók kutatásában és irodalmában nem vagy csak részben jelennek meg. Például a késleltetés a végrehajtó funkciók vizsgálatában is megjelenik, azonban vagy a gátlás egyik részfolyamataként (Gerstadt, Hong és Diamond, 1994), vagy pedig bizonyos cselekvések, egy kísértésnek való ellenállás kapcsán (pl. vonzó, érdekes játékkal nem lehet játszani, lásd Calkins, 1997). Ezzel szemben az erôfeszítés alapú kontroll vizsgálata során jobban fókuszálnak a jutalmazás késleltetésére (pl. keksz mint jutalom megevésének késleltetése), illetve a közben fellépố emóciók (pl. szomorúság, elkeseredés vagy öröm) detektálására (Spinrad és mtsai, 2007).

A másik legfontosabb ok, ami miatt különbözônek tekinthetố a két konstruktum, az empirikus vizsgálatok eredményeiben rejlik. Bár kevés empirikus kutatás áll rendelkezésre, ami megfelelően alátámasztaná a két konstruktum közötti kapcsolatot, a kisgyermekkorban végzett vizsgálatok többsége az erôfeszítés alapú kontroll és végrehajtó funkciók között mérsékelt összefüggést mutatott ki (Carlson és Moses, 2001; Davis, Bruce és Gunnar, 2002; Gerardi-Caulton, 2000; Rothbart, Ellis, Rueda és Posner, 2003), ami alátámasztja a különállóság feltételezését. 
Magasabb életkorban ehhez hasonló eredmények születtek. Bridgett és munkatársai (2013) serdülőkkel végzett vizsgálatainak célja éppen a két konstruktum közti hasonlóságok és különbségek kimutatása volt. Eredményeik néhol egymásnak ellentmondó, néhol egymást részben magyarázó válaszokat szolgáltattak. Egyik vizsgálatukban az erőfeszítés alapú kontroll és végrehajtó funkciók szoros kapcsolatát mutatták ki, máskor pedig azt találták, hogy az erôfeszítés alapú kontroll csak a munkamemória monitorozó folyamatával mutatott összefüggést, de a gátló funkcióval nem (Bridgett és mtsai, 2013). Egy harmadik vizsgálatukban az erôfeszítés alapú kontroll és a végrehajtó funkciók monitorozó folyamata összefüggést mutatott a negatív tapasztalatokkal, mindamellett a végrehajtó funkciók gátló komponense csak a negatív tapasztalatokkal mutatott összefüggést. Ellentmondó eredményeikból egyrészt a két fogalom közti átfedést emelik ki, másrészt rávilágítanak a különbözô típusú méróeszközök (pl. szülôi beszámolók, laboratóriumi helyzet) használatából eredô ellentmondásokra. Ezek szerint, ha ugyanarról a konstruktumról eltérô módszerekkel eltérô eredmények születnek, a pontosabb értelmezés miatt komplex vizsgálati módszerek együttes alkalmazása javallott (önmagában sem a kérdôíves módszer, sem pedig a laboratóriumi kísérleti módszerek nem elegendóek).

Egy másik különbség, ami az összehasonlító elemzésekból hiányzik, azonban a két terület szakirodalmának áttanulmányozásából kiderül, a fogalmak értelmezésében (más fogalmakkal való összevetésében) mutatkozik meg. Míg a végrehajtó funkcióknál olyan fogalmi elôzmények jelennek meg, amelyek a korábbi szakirodalmakban más elnevezéssel hasonló folyamatokat fedtek le (pl. a metakognitív folyamatokkal, a BIS/BAS rendszerrel való összevetés, lásd Diamond, 2013), az erófeszítés alapú kontroll értelmezése kapcsán elmaradnak ezek az összehasonlítások, és nem látunk törekvést arra, hogy a fogalmat más értelmezésekkel összevessék. Pedig az akaraterô fogalmának beemelése és összehasonlítása az erôfeszítés alapú kontroll fogalmával megalapozott lenne (Baumeister és Tierney, 2013). Igaz ugyan, hogy az akaraterô értelmezésében sem találunk egyértelmú megközelítést, de egy újabb kihívás és kutatási kérdés lehetne a területek összevetése, hiszen a háttérben hasonló folyamatok múködnek, mint az erőfeszítés alapú kontroll/végrehajtó funkciók esetében. Például Baumeister (2002) akaraterô fogalma az önkontrollkutatásokból indul ki, és olyan szelffolyamatként jelenik meg, ami az éntudatossággal (énkép, önértékelés, énészlelés), az énábrázolással (self-presentation) és a végrehajtó funkciókkal (választás, cselekvéskezdeményezés, akarat) együtt az önszabályozásban integrálódik. Az akaraterô Baumeister erômodelljében (Strenght Model) véges erôforrásként jelenik meg, amit affektív (személyes értékek, normák, erkölcs, szociális elvárások stb.) és kognitív (választás, akarat stb.) folyamatok egyaránt befolyásolnak (Baumeister és Tierney, 2013). Látszik, hogy ez a felfogás egy többdimenziós akarateró fogalmat mutat be, amelyben ötvözôdnek a személyiség személyes komponensei és kognitív folyamatai is. Egy másik megközelítésben, Kelly McGonigal (2015) az akaraterôt olyan kontrollfolyamatnak tekinti, amely egyfajta evolúciós innováció eredménye (az agy prefrontális kérgének kifejlődése révén), és amelynek segítségével a rövid távú, gyors kielégülést ígérô célok/tevékenységek helyett a hosszú távú célok elérését szolgáló tevékenységek végzése mellett döntünk. Az akaraterô nemcsak azért lehet szinonimája az erôfeszítés alapú kontrollnak, mert értelmezésében megjelenik a gátlás folyamata, hanem mert ösztön- 
szerú, az idegrendszer által meghatározott funkcióként írják le (McGonigal, 2015), ami a temperamentum értelmezéséhez áll közelebb. Ezekből a felvetésekbôl is látszik, hogy érdemes lenne a továbbiakban az akaraterô fogalmát is beemelni, és kapcsolatát az erófeszítés alapú kontrollal, a végrehajtó funkciókkal vizsgálni az önszabályozás komplex értelmezése során.

Többen a két fogalom közti különbséget a megjelenésükben, és az önszabályozásban betöltött szerepükben látják. Az erôfeszítésalapú kontroll megjelenését és szerepét a korai életkorra teszik, amit genetikai és környezeti tényezôk formálnak (Kagan és Snidman, 2004), míg a végrehajtó funkciókat magasabb rendú és késôbb fejlôdô kognitív folyamatokként értelmeznek, melyek beavatkozás és fejlesztés által szintén jól alakíthatók (Garon és mtsai, 2008; Zelazo és mtsai, 2012).

\section{AZ ERŐFESZÍTÉS ALAPÚ KONTROLL ÉS VÉGREHAJTÓ FUNKCIÓK INTEGRÁLÁSA AZ ÖNSZABÁLYOZÁSBAN}

A két különbözó elméleti (viselkedéses/temperament alapú és kognitív/neurálishálózat-szintû) megközelítés mindegyike az önszabályozást olyan komplex ernyôfolyamatnak tekinti, amelyben mind az erôfeszítés alapú kontroll, mind pedig a végrehajtó funkciók szerepe megnyilvánul. Az önszabályozás olyan többkomponensú, hierarchikusan szervezett folyamatként értelmezhetô, amely során az egyén kontrollálja gondolatait, érzelmeit és viselkedését (Morf és Horvath, 2010; Kruglanski, Orehek, Higgins, Pierro és Shalev, 2010) az általa kitüzött rövid és hosszú távú célok elérése közben (Matthews, Schwean, Campbell, E., Saklofske és Mohamed, 2000). Ahhoz, hogy egy terv és egy hosszú távú cél teljesíthetô legyen, szükség van a figyelem szándékos fókuszálására (a cél szem előtt tartása), a gátló funkciókra (a gyors jutalommal kecsegtetô viselkedés elnyomása) és a kívánt viselkedés aktivizálására (továbbra is kitartani a célhoz vezetô viselkedés mellett) (Karoly, 2010). Éppen ezért szükségszerúvé vált egy integratív szemléletú modell felvázolása, amely lehetôvé teszi nemcsak az önszabályozás alaposabb megértését és vizsgálatát, hanem a két területen elért eredmények szintetizálását, a fogalmak közti átfedések tisztázását, valamint egymáshoz való viszonyát is.

Többen egymás kiegészítôiként, mintsem összeegyeztethetetlen komponensként értelmezik az erôfeszítés alapú kontrollt és végrehajtó funkciókat (Liew, 2012; Zhou és mtsai, 2012). Ezt a feltételezést egyelôre még kevés empirikus kutatás támasztja alá (pl. Bridgett és mtsai, 2013), azonban a felvázolt elméleti szempontok éppen ennek a tisztázását tennék lehetôvé.

Az egyik lehetséges megközelítés az lehetne, ha a jövôben az önszabályozás kutatásán belül mindkét konstruktum vizsgálata együttesen megvalósulna, a különbözó folyamatok múködésének, összefüggéseinek, a latens struktúrák felvázolásának érdekében (1. Zhou és mtsai, 2012). Bár a két eltérô hagyományú kutatási keretben megjelennek azonos folyamatok (mint a gátlás, váltás, figyelem), azok szerepe és megvalósulása eltérô lehet (Blair és Ursache, 2011; Spinrad és mtsai, 2007; Gerstadt, Hong és Diamond, 1994). Ez a Friedman és Miyake (2017) által felvázolt egységesség/diverzitás modell mentén is elképzelhetô, azonban empirikus eredmények hiányában nem meghatározható pontosan, hogy mely folyamatok egységesek, és milyen kontextuális különbségek 
adják az önszabályozás diverzitását. Az elméleti háttér alapján relevánsnak tûnik az, hogy egy-egy komplex szituáció szabályozásában (pl. tanulás vizsgára, érettségire vagy szociális konfliktusok kezelése) a temperamentum vonásai (erófeszítés alapú kontroll), valamint a magasabb szintû kontrollfolyamatok (végrehajtó funkciók) egyaránt szerepet játszanak és múködésbe lépnek. A kérdés az, hogy ezt milyen mértékben, milyen tényezók által meghatározottan teszik, amire csak jól átgondolt és több területet érintô empirikus vizgsálatok megszervezése által adhatunk választ.

Ugyanakkor a fentebb leírt összegzésbôl az is kiderül, hogy érdemes többféle mérési eljárás (pl. kérdôíves módszer, egyéni feladathelyzetek) együttes alkalmazását bevetni ahhoz, hogy az egyes képességek és folyamatok múködésérôl megbízható eredményt kaphassunk (Bridgett és mtsai, 2013).

$\mathrm{Az}$ életkori minta kiszélesítésével, valamint longitudinális vizsgálatok megszervezésével magyarázatot kaphatnánk azokra az eddigi egymásnak ellentmondó kutatási eredményekre, amelyek az egyes folyamatok (pl. gátlás, figyelem) szerepét és funkcióját eltérônek találták a különbözô korosztályok esetében (Blair és Ursache, 2011; Bridgett és mtsai, 2013). Mindezek mellett olyan fejlesztést megalapozó kutatásokra kerülhetne sor, amelyekbôl kiderülne a környezet befolyásoló szerepe, a fejlôdést és fejlesztést meghatározó tényezók számbavétele.

Az önszabályozás komplex (erőfeszítés alapú kontroll és végrehajtó funkciók együttes) vizsgálatával lehetôvé válna a szociális, emocionális és kognitív területekkel való összefüggések feltárása és az iskolai adaptációban betöltött szerepének átfogó értelmezése is (Zhou és mtsai, 2012). Jelen tanulmány az erôfeszítés alapú kontroll fogalmának átfogó magyar nyelvú ismertetésével, a végrehajtó funkciókkal való összehasonlítással és az elméleti keretek felvázolásával az elsố lépés ebben a folyamatban.

\section{IRODALOM}

Anderson, S. W., Damasio, H., Tranel, D., \& Damasio, A. R. (2000). Long-term sequelae of prefrontal cortex damage acquired in early childhood. Developmental Neuropsychology, 18(3), 281-296.

Baddeley, A. (1986). Working Memory. New York: Oxford University Press.

Barnett, W. S., Jung, K., Yarosz, D. J., Thomas, J., Hornbeck, A., Stechuk, R. et al. (2008). Educational effects of the Tools of the Mind curriculum: A randomized trial. Early Childhood Research Quarterly, 23, 299-313.

Baumeister, R. F. (2002). Ego depletion and self-control failure: An energy model of the self's executive function. Self and Identity, 1(2), 129-136.

Baumeister, R. F., \& Tierney, J. (2013). Akaraterô. A legnagyobb belsố erô újrafelfedezése. Budapest: Ursus Libris.

Bierman, K. L., Nix, R. L., Greenberg, M. T., Blair, C., \& Domitrovich, C. E. (2008). Executive functions and school readiness intervention: Impact, moderation, and mediation in the Head Start REDI program. Development and Psychopathology, 20, 821-843.

Blair, C., \& Razza, R. P. (2007). Relating effortful control, executive function, and false belief understanding to emerging math and literacy ability in kindergarten. Child Development, 78, 647-663. 
Blair, C., \& Ursache, A. (2011). A bidirectional model of executive functions and self-regulation. In K. D. Bohs, \& R. F. Baumeister (Eds), Handbook of Self-regulation: Research, Theory, and Applications (2nd ed., pp. 300-320). New York, NY: The Guilford Press.

Bodrova, E., \& Leong, D. J. (2007). Tools of the Mind: The Vygotskian Approach to Early Childhood Education (2nd ed.). Columbus, OH: Merrill/Prentice Hall.

Bridgett, D. J., Oddi, K. B., Laake, L. M., Murdock, K. W. és Bachmann, M. N. (2013). Integrating and differentiating aspects of self-regulation: Effortful control, executive functioning, and links to negative affectivity. Emotion, 13(1), 47-63.

Buda M. (2014). Durva fiúk - szelíd lányok? Iskolás lányok zaklató viselkedése. In Németh N. V. (szerk.), Képzók és képzettek: Pillanatfelvételek a 21. század tanárképzéséról és tanárairól (pp. 133-154). Szeged: Belvedere Meridionale.

Bush, G., Luu, P., \& Posner, M. I. (2000). Cognitive and emotional influences in anterior cingulate cortex. Trends in Cognitive Science, 4, 215-222.

Calkins, S. D. (1997). Cardiac vagal tone indices of temperamental reactivity and behavioral regulation in young children. Developmental Psychobiology, 31, 125-135.

Carlson, S. (2005). Developmentally sensitive measures of executive function in preschool children. Developmental Neuropsychology, 28, 595-616.

Carlson, S. M., \& Moses, L. J. (2001). Individual differences in inhibitory control and children's theory of mind. Child Development, 72, 1032-1053.

Csépe V. (2005). Kognitív fejlôdés-neuropszichológia. Budapest: Gondolat-Infonia.

Davis, E. P., Bruce, J., \& Gunnar, M. R. (2002). The anterior attention network: Associations with temperament and neuro endocrine activity in 6-year-old children. Developmental Psychobiology, 40, $43-56$.

Dennis, T. A., \& Brotman, L. M. (2003). Effortful control, attention, and aggressive behavior in preschoolers at risk for conduct problems. Annals of the New York Academy of Sciences, 1008, 252-255.

Diamond, A. (2013). Executive functions. Annual Review of Psychology, 64, 135-168.

Diamond, A., Barnett, W. S., Thomas, J., \& Munro, S. (2007). Preschool program improves cognitive control. Science, 30, 1387-1388.

Eisenberg, N., Hofer, C., Sulik, M., \& Spinrad, T. L. (2014). Effortful control and its socioemotional consequences. In J. J. Gross (Ed.), Handbook of Emotion Regulation (2nd ed., pp. 157-172). New York, NY: Guilford Press.

Eisenberg, N., Zhou, Q., Spinrad, T. L., Valiente, C., Fabes, R. A., \& Liew, J. (2005). Relations among positive parenting, children's effortful control, and externalizing problems: A three-wave longitudinal study. Child Development, 76, 1055-1071.

Evans, D. E., \& Rothbart, M. K. (2007). Development of a model for adult temperament. Journal of Research in Personality, 41, 868-888.

Fan, J., McCandliss, B. D., Fossella, J., Flombaum, J. I., \& Posner, M. I.(2005). The activation of attentional networks. Neuroimage, 26, 471-479.

Friedman, N. P., \& Miyake, A. (2017). Unity and diversity of executive functions: Individual differences as a window on cognitive structure. Cortex, 86, 186-204.

Garon, N., Bryson, S. E., \& Smith, I. M. (2008). Executive function in preschoolers: A review using an integrative framework. Psychological Bulletin, 134, 31-60.

Garon, N., \& Moore, C. (2006). Negative affectivity predicts individual differences in decision making for preschoolers. The Journal of Genetic Psychology, 167(4), 443-462.

Gerardi-Caulton, G. (2000). Sensitivity to spatial conflict and the development of self-regulation in children 24-36 months of age. Developmental Science, 3, 397-404. 
Gerstadt, C. L., Hong, Y. J., \& Diamond, A. (1994). The relationship between cognition and action: Performance of children 3.5-7 years old on a Stroop-like day-night test. Cognition, 53, 129-153.

Gioia, G., Isquith, P. K., Retzlaff, P., \& Espy, K. (2002). Confirmatory factor analysis of the Behavior Rating Inventory of Executive Function (BRIEF) in a clinical sample. Child Neuropsychology, 4, 249-257.

Goldsmith, H. H., Pollak, S. D., \& Davidson, R. J. (2008). Developmental neuroscience perspectives on emotion regulation. Child Development Perspectives, 2, 132-140.

Hughes, C., Ensor, R., Wilson, A., \& Graham, A. (2010). Tracking executive function across the transition to school: A latent variable approach. Developmental Neuropsychology. 35(1), 20-36.

Jacques, S., \& Marcovitch, S. (2010). Development of executive function across the lifespan. In W. F. Overton (Ed.), Handbook of Life-span Development: Vol. 1. Cognition, Biology, and Methods Across the Lifespan (pp. 431-466). Hoboken, NJ: Wiley.

Kagan, J., \& Snidman, N. (2004). The Long Shadow of Temperament. Cambridge, MA: Harvard University Press.

Kam, C., Greenberg, M. T., \& Kusche, C. A. (2004). Sustained effects of the PATHS curriculum on the social and psychological adjustment of children in special education. Journal of Emotional and Behavioral Disorders, 12, 66-78.

Karoly, P. (2010). Goal systems and self-regulation: An individual differences perspective. In R. H. Hoyle (Ed.), Handbook of Personality and Self-regulation (pp. 218-242). Chichester: Blackwell Publishing Ltd.

Klingberg, T. (2010). Training and plasticity of working memory. Trends in Cognitive Sciences, 14, 317-324.

Kruglanski, A. W., Orehek, E., Higgins, E. T., Pierro, A., \& Shalev, I. (2010). Modes of self-regulation: Assessment and locomotion as independent determinants in goal pursuit. In R. H. Hoyle (Ed.), Handbook of Personality and Self-regulation (pp. 375-402). Chichester: Blackwell Publishing Ltd.

Lengua, L. J., Honorado, E., \& Bush, N. R. (2007). Contextual risk and parenting as predictors of effortful control and social competence in preschool children. Journal of Applied Developmental Psychology, 28, 40-55.

Liew, J. (2012). Effortful control, executive functions, and education: Bringing self-regulatory and social-emotional competencies to the table. Child Development Perspectives, 6(2), $105-111$.

Liew, J., McTigue, E. M., Barrois, L., \& Hughes, J. N. (2008). Adaptive and effortful control and academic self-efficacy beliefs on literacy and math achievement: A longitudinal study on 1st through 3rd graders. Early Childhood Research Quarterly, 23, 515-526.

Lonigan, C. J., \& Phillips, B. M. (2001). Temperamental influences on the development of anxiety disorders. In M. W. Vasey \& M. R. Dadds (Eds), The Developmental Psychopathology of Anxiety (pp. 60-91). New York: Oxford University Press.

Matthews, G., Schwean, V. L., Campbell, S. E., Saklofske, D. H., \& Mohamed, A. A. R. (2000). Personality, self-regulation, and adaptation: A cognitive-social framework. In M. Boekaerts, P. R. Pintrich \& M. Zeidner (Eds), Handbook of Self-regulation (pp. 171-209). San Diego: Academic Press.

McClelland, M. M., Cameron, C. E., Connor, C. M., Farris, C. L., Jewkes, A. M., \& Morrison, F. J. (2007). Links between behavioral regulation and preschoolers' literacy, vocabulary, and math skills. Developmental Psychology, 43, 947-959.

McCloskey, G., Perkins, L. A., \& Van Divner, B. (2009). Assessment and Intervention for Executive Function Difficulties (School-Based Practice in Action). New York: Taylor \& Francis Group. 
MacDonald, K. B. (2008). Effortful Control, Explicit Processing, and the Regulation of Human Evolved Predispositions. Psychological Review, 115(4), 1012-1031.

McGonigal, K. (2015). Akaraterö-ösztön. Budapest: Ursus Libris.

Mischel, W., Ayduk, O., \& Mendoza-Denton, R. (2003). Sustaining delay of gratification over time: A hot-cool systems perspective. In G. Loewenstein, D. Read, \& R. Baumeister (Eds), Time and Decision: Economic and Psychological Perspectives on Intertemporal Choice (pp. 175-200). New York: Russell Sage Foundation.

Miyake, A., Friedman, N. P., Emerson, M. J., Witzki, A. H., \& Howerter, A. (2000). The unity and diversity of executive functions and their contributions to complex „frontal lobe” tasks: A latent variable analysis. Cognitive Psychology, 41, 49-100.

Moffitt, T. E., Arseneault, L., Belsky, D., Dickson, N., Hancox, R. J. et al. (2011). A gradient of childhood self-control predicts health, wealth, and public safety. Proceedings of the National Academy of Sciences of the USA, 108, 2693-2698.

Morf, C. C., \& Horvath, S. (2010): Self-regulation processes and their signatures: Dynamics of the self-system. In R. H. Hoyle (Ed.), Handbook of Personality and Self-regulation (pp. 117-143). Chichester: Blackwell Publishing Ltd.

Patrick, M. E., Blair, C., \& Maggs, J. L. (2008) Executive function, behavioral approach and risk behavior among female college students. Journal of Clinical and Experimental Neuropsychology, 30, 449-462.

Ponitz, C. C., McClelland, M. M., Jewkes, A. M., Connor, C. M., Farris, C. L., \& Morrison, F. J. (2008). Touch your toes! Developing a direct measure of behavioral regulation in early childhood. Early Childhood Research Quarterly, 23, 141-158.

Putnam, S. P., Gartstein, M. A., \& Rothbart, M. K. (2006). Measurement of fine-grained aspects of toddler temperament: The Early Childhood Behavior Questionnaire. Infant Behavior and Development, 29(3), 386-401.

Redick, T. S., Gay, C. E., Calvo A., \& Engle, R. W. (2011). Working memory capacity and Go/ No-Go task performance: Selective effects of updating, maintenance, and inhibition. Journal of Experimental Psychology, 37(2), 308-324.

Rothbart, M. K., \& Ahadi, S. A. (1994). Temperament and the development of personality. Journal of Abnormal Psychology, 103, 55-66.

Rothbart, M. K., \& Bates, J. E. (2006). Temperament. In N. Eisenberg, W. Damon, \& R. M. Lerner (Eds), Handbook of child psychology: Vol. 3. Social, Emotional, and Personality Development (6th ed., pp. 99-166). Hoboken, NJ: Wiley.

Rothbart, M. K., Ahadi, S. A., Hersey, K. L., \& Fisher, P. (2001). Investigations of temperament at three to seven years: The Children's Behavior Questionnaire. Child Development, 72, 1394-1408.

Rothbart, M. K., Sheese, B. E., \& Posner, M. I. (2007). Executive attention and effortful control: Linking temperament, brain networks, and genes. Child Development Perspectives, 1(1), 2-7.

Rothbart, M., Ellis, P., Rueda, R., \& Posner, M. (2003). Developing mechanisms of temperamental effortful control. Journal of Personality, 71, 1113-1143.

Shallice, T. (1988). From Neuropsychology to Mental Structure. Cambridge, UK: Cambridge University Press.

Simonds, J. Kieras, J. E., Rueda M. R., \& Rothbart, M. K. (2007). Effortful control, executive attention, and emotional regulation in 7-10-year-old children. Cognitive Development, 22, 474-488.

Spinrad, T. L., Eisenberg, N., Gaertner, B., Popp, T., Smith, C. L., Kupfer, A., Greving, K., Liew, J., \& Hofer, C. (2007). Relations of maternal socialization and toddlers' effortful control to children's adjustment and social competence. Developmental Psychology, 43(5), 1170-1186. 
Stroop, J. R. (1935). Studies of interference in serial verbal reactions. Journal of Experimental Psychology, 18, 643-662.

Tánczos T. (2012). A végrehajtó funkciók szerepe az iskolában és a verbálisfluencia-tesztek. Iskolakultúra, 12(5), 38-51.

Tánczos T., Janacsek K., \& Németh D. (2014). A munkamemória és végrehajtó funkciók kapcsolata az iskolai teljesítménnyel. Alkalmazott Pszichológia, 14(2), 55-75.

Valiente, C., Lemery-Chalfant, K., Swanson, J., \& Reiser, M. (2008). Prediction of children's academic competence from their effortful control, relationships, and classroom participation. Journal of Educational Psychology, 100, 67-77.

Vijayakumar, N., Whittle, S., Dennison, M., Yücel, M., Simmons, J., \& Allen N. B. (2014). Development of temperamental effortful control mediates the relationship between maturation of the prefrontal cortex and psychopathology during adolescence: A 4-year longitudinal study. Developmental Cognitive Neuroscience, 9, 30-43.

Wiebe, S. A., Sheffield, T., Nelson, J. M., Clark, C. A. C., Chevalier, N., \& Espy, K. A. (2011). The structure of executive function in 3-year-old children. Journal of Experimental Child Psychology, 108(3), 436-452.

Zelazo, P. D. (2004). The development of conscious control in childhood. Trends in Cognitive Sciences, 8, 12-17.

Zelazo, P. D., \& Cunningham, W. (2007). Executive function: Mechanisms underlying emotion regulation. In J. Gross (Ed.), Handbook of Emotion Regulation (pp. 135-158). New York: Guilford.

Zelazo, P. D., Craik, F. I. M., \& Booth, L. (2004). Executive function across the life span. Acta Psychologica, 115, 167-183.

Zhou, Q., Chen, S. H., \& Main, A. (2012). Commonalities and differences in the research on children's effortful control and executive function: A call for an Integrated model of selfregulation. Child Development Perspectives, 6(2), 112-121.

\section{EFFORTFUL CONTROL AND EXECUTIVE FUNTCTIONS IN SELF-REGULATION}

\section{MOLNÁR, ÉVA}

Current researches found that the self-regulatory skills are essential for school readiness and future achievement. Usually researchers study these processes from either a behavioral and temperament-based approach or a cognitive /neural systems approach. The temperament-based framework often focuses on effortful control, whereas the cognitive or neuroscience framework often focuses on executive functions. Although literatures on effortful control and executive functions come from different research traditions, they show common aspects and components. The measurement of effortful control and comparison with executive functions is unfamiliar in Hungarian researches. The article resumes new findings of the different research areas, draws up the theoretical background of the effortful control and executive functions' integration.

Keywords: effortful control, executive functions, self-regulation 